\title{
До ДИСКУСІї ЩОДо ОЩночнИХ пОНЯТь В АДМІНІСТРАТИВНОМУ ПРАВІ
}

\author{
БААДЖИ Наталія Анатоліївна - викладач кафедри мовної підготовки \\ Одеського державного університету внутрішніх справ
}

DOI:10.32782/NP.2020.1.7

Статья посвящена определению сущности оченочных понятий через призму анализа мнений различныхх ученъих юристов отечественной и зарубежной юридической мвисли. При отсутствии взвешенного подхода к определению оченочных понятий в правоприменительной деятельности, их толкование представляет определеннве трудности для субъектов правоприменения. Разнообразие и широта сберь применения оченочнъх понятий в административном праве намного больше, чем в других отраслях права, а поэтому требует обобщения и определенной стандартизаиии. Сделан въивод о необходимости систематического анализа административно-правовъгх норм, а также внедрение практики стандартизачии их применения правоприменительными органами.

Ключевъе слова: оценочнъие понятия, административное усмотрение, дискреция, толкование, нормотворчество, провоприменение

\section{Постановка проблеми}

Постійні правові перетворення, які мають місце в нашій країні насамперед спрямовані на удосконалення правової системі із реалізацією верховенства права.

Динамічний характер виконавчо-розпорядчої діяльності, іiі різноманітність та мінливість вимагає розширеного простору в правовому регулюванні дозволеної поведінки й можливих варіантів ії наслідків. У процесі реалізації такого положення та 3 огляду на нього, у правозастосовній діяль- ності суб'єктів публічного адміністрування дедалі предметніше використовуються норми-принципи та норми-цілі. У цих нормах приписи держави не конкретизовані, а мають оціночний характер.

За умов кардинальних перетворень, нормативно-правової сфери адміністративного права для забезпечення ефективної реалізації аднімістративної діяльності є вкрай важливим виважене та правильне використання оціночних понять, які є невід'ємною складовою адміністративного розсуду.

Проблема постає в тому, що без єдиної науково-теоретичної концепції щодо оціночних понять, без сформованої та науково обгрунтованої теорії неможливо буде їх виважене та ефективне використання у правозастосовній діяльності.

Метою даної публікації є питання щодо правильного тлумачення оціночних понять суб'єктами правозастосування, адже досі відсутні чітко визначені принципи оцінювання даних понять. Можливість неоднозначного тлумачення оціночних понять може призвести до створення можливостей., при яких перевага буде надаватись суб'єктивному принципу застосування адміністративного розсуду, а не принципу законності, доцільності або неупередженості, що неминуче призводить до зловживання повноваженнями.

Отже проблематика оціночних понять адміністративного розсуду органів публічної адміністрації була і залишається однією 
iз дискусійних, як для правової спільноти, так і для правозастосовників.

Актуахьність даної проблематики також обумовлюються суттевим зростанням принципового значення тлумачення нормативно-правових актів у процесі правотворення і правозастосування. Невід'ємною складовою усієї системи нормативно-правових актів завжди було і залишається адміністративне законодавство, яке відрізняється значним обсягом, ускладненим змістом, розмаїттям зовнішніх форм вираження, розпорошеністю, що й обумовлює певні складнощі у нормотворенні, а відповідно, й тлумаченні.

\section{Ступінь дослідженності}

У вітчизняній науковій думці оціночним поняттям окрема увага не приділялася, на відміну від кримінально-правової або цивільно-процесуальної наук. Можна згадати фундаментальні наукові праці М. Бару, О. Степанової та ін. (у трудовому праві), М. Панова, В. Кудрявцева та ін. (у кримінальному праві). Щодо адміністративноправової наукової літератури, то можна виділити низку фундаментальних робіт за авторством В.Б. Авер'янова, С.С. Алексєєва, Д.М. Бахраха, В.А. Біленко, В.А. Біленко, Д.К. Василяка, В.К. Колпакова, Т.О. Коломоєць, С.А. Рєзанова.

Отже що стосується наукової обгрунтованності в адміністративно-правовій науці стосовно дослідження оціночних понять в контексті застосування адміністративного розсуду огранами публічної адміністрації, то у наявності прогалина.

В юридичній літературі оціночні поняття - це поняття, зміст яких недостатньо чи взагалі не визначено теорією права. [14].

Одним 3 аспектів вирішення проблеми застосування розсуду (дискреції), і відповідно захисту прав та свобод громадян, які порушені під час реалізації дискреційних повноважень, є визначення його нормативної основи. Основним способом законодавчого закріплення адміністративного розсуду в законодавстві $є$ використання оціночних понять.

Оціночні поняття невідривно пов'язані iз поняттям адміністративний розсуд, адже це елемент правозастосовної діяльності, який характеризується певною свободою суб'єкта публічної адміністрації, органу чи посадової особи, у правовому вирішенні того чи іншого питання, яка надається з метою прийняття раціонального, мотивованого і обгрунтованого рішення у справі, в межах визначених нормами права, а тому невідривно пов' язаний із оціночними поняттями, кількість яких в сучасних правових актах не зменшується.

Оскільки в сучасному правознавстві в дослідженнях диспозитивної поведінки учасників правовідносин не вичерпується використання авторами понять «розсуд» та «дискреція» та їхніх похідних. Поряд 3 ними, часто із синонімічними значеннями автори вживають оціночні поняття, якими правозастосовники користуються при прийнятті рішень, а саме «альтернатива», «згідно бачення», «вибір», «вирішення», «волевиявлення», «на думку», «межі», «переконання», «повноваження», «на погляд», «рішення», а також їхні похідні, та інші слова та словосполучення. Таким чином, у правовій науці сформувалось в цілому єдине розуміння сутності розсуду та дискреції як правових феноменів. Її призначення полягає в тому, щоб в ситуації повної або відносної невизначеності в законі правозастосовник міг би з низки правомірних альтернатив вибрати оптимальне рішення, яке дозволить найбільш ефективно і справедливо реалізувати намір законодавця щодо тієї частини правовідносин у яких розсуд (дискреція) виступає правовим регулятором по оптимізації управлінського впливу, у тому числі коли правова система не містить чітких механізмів вирішення колізій, однак виникає потреба оперативно та гнучко відреагувати на специфіку окремих юридичних фактів, ситуацій та правовідносин у цілому.

Щоб з' ясувати сутність категорії «оціночні поняття», необхідно проаналізувати деякі точки зору науковців-юристів щодо даного питання. Адже підгрунтям удосконалення нормативно-правової бази країни є ретельний аналіз вітчизняної та міжнародної правової доктрини.

В. Ігнатенко вважав, що оціночними $\epsilon$ такі поняття, у змісті яких узагальнені «ти- 
пові ознаки певних правозначимих явищ» [5, с.9]. Необхідно зауважити, що саме в радянський час закладено фундамент подальших досліджень феномена оціночних понять, проте визначення їх змісту, характерне для того періоду, все ж таки недостатньо повне й деякі суттєві ознаки оціночних понять не враховувались вченими [10, с.93].

В. Косович вважає, що оціночно-правове поняття - це виражена в юридичній нормі абстрактна характеристика соціальної (особистої, групової тощо) значущості реальних або потенційних фактів, що має бути неодмінно конкретизована пі час його застосування чи реалізації, завдяки чому забезпечено юридичне реагування держави на всі індивідуалізовані факти, яким притаманна зафіксована в юридичній нормі значущість $[7$, c.43].

Автор дотримується схожої думки M.I. Бару, який визначає, що з погляду законності бажано не тільки скрупульозне уточнення самого поняття, а й встановлення повного переліку випадків, що підпадають під те або інше поняття. I тільки при неможливості вичерпати усі випадки, охоплювані цим поняттям, можна обмежитися приблизним переліком [2, с.105].

Як слушно зауважує С.А. Резанов предмети і явища, що позначаються через оціночні поняття, неможливо типізувати навіть у самому загальному плані, і тому такі оціночні поняття лише орієнтують правозастосувача, визначаючи загальний напрямок його оціночної діяльності. До їх числа відносяться формулювання «у необхідних випадках», «у виняткових випадках», «у випадках, що не терплять зволікання», «як правило». Роль такого роду оціночних понять у адміністративно-правовій нормі може бути різноманітною. [11, с.167].

Доволі суттєво надає визначення оціночним поняттям О. Веренкіотова. На підставі аналізу думок учених з указаної теми [2, с.30-33]. формулюе власну дефініцію оціночних понять у широкому та вузькому розуміннях. Зокрема, оціночне поняття права - це закріплене в нормах права уявлення (абстрактна думка), що відображає в собі різні емпіричні властивості явищ шляхом закріплення їх право значущих типів i зумовлює здійснення на його основі індивідуального піднормативного регулювання та конкретизації суспільних відносин чи самостійного оцінювання конкретної ситуації 3 боку суб'єктів правозастосування (широке розуміння). Оціночне поняття нормативноправового акта - це закріплений у нормі права загальний припис, зміст якого не містить чітко визначеної, завершеної системи ознак, що зумовлює здійснення індивідуального під нормативного регулювання суб’єктом правозастосування шляхом вільного оцінювання в межах конкретної правозастосовної ситуації (вузьке розуміння) [3, с.14].

В свою чергу критерії оцінки фактів i явищ, позначених оціночними поняттями, дає практика, їх можна знайти, лише знаючи умови конкретної ситуації [11, с.167]. Отже, оціночні поняття дають правозастосовнику в межах, що припускаються законом, можливість адміністративного розсуду, вільної оцінки фактів.

У підримку думки про взаємозв'язок оціночних понять та адміністративного розсуду правозастосовника висловлюеться С. Черноус, визначаючи даний феномен, як закріплене в нормі права поняття, зміст якого не містить чітко визначеної, завершеної системи ознак, що зумовлює здійснення його конкретизації в кожному окремому індивідуально визначеному випадку на розсуд правозастосовувача [15, с.28].

Російський науковець Д. Аевіна дає досить влучне визначення оціночному поняттю, як закріпленому в нормах права поняття, що характеризує найбільш загальні властивості різних предметів, явищ, дій, процесів., спеціально не конкретизоване законодавцем $з$ метою надання такої можливості суб'єкту, що застосовує право шляхом вільного оцінювання. [9, с.9]. Aле 3 даного визначення автоматично постає питання щодо меж вільного оцінювання, а також неможливості закріплення в нормативному акті відповідальності за зловживання можливістю «вільного» оцінювання правової ситуації.

У адміністративному праві, розглядаючи особливості оціночних понять, закріплених у КпАП, такі автори, як Т.О. Коломоєць, В.А. Біленко розглядають їхні функції, які 
відображають сутність таких понять, а отже відображають ознаки цього правового явища [6, с.82]. Вони зазначають, що оціночні поняття у адміністративно-правовому регулювання покликані охопити будь-які життєві ситуації задля досягнення мети правозастосування, а отже виконують функцію нормативного регулювання. Крім того, до функцій оціночних понять науковці відносять функції відображення, фіксації, прогнозування, передавання правової інформації, індивідуального нормативного регулювання, яка поєднує, з одного боку, певну самостійність суб'єкта правозастосування, а, 3 іншого боку, - певні обмеження абсолютної самостійності. Отже, з аналізу викладених функцій приходимо до висновку, що в адміністративно-деліктному праві акцент також зміщується у бік застосування імперативного методу при здійсненні правозастосовної діяльності з використанням таких понять.

Існує думка, що розвиток права йде шляхом звуження кола оціночних понять у праві. Aле яким би досконалим не було право, воно не може повністю обійтись без оціночних понять, зважаючи на обмеженість можливостей визначеного тлумачення юридичних фактів.

Aле зважаючи на розмаїття адміністративного права, велика кількість понять тлумачиться «вільно» або на розсуд правозастосовника. Зокрема, в матеріальному адміністративному праві на прикладі окремих нормативно-правових актів, можна виділити наступні: «консультативно-дорадчі функції», «шанобливо», «висока культура спілкування», «забезпечення ефективної роботи», «творчість у роботі», «справедливе і шанобливе ставлення», «належні для високопродуктивної роботи умови праці», «вчинок державного службовця, який порочить його як державного службовця або дискредитує державний орган, у якому він працює», «неповна службова відповідність», «ділові якості особи», «виняткові випадки», «державні службовці, які досягли найкращих результатів у роботі, виявляють ініціативність», «принципова незгода», «етичні перешкоди», «достатні матеріальні умови для незалежного виконання службових обов'язків», «особливі трудові заслуги» та інші (ст.ст.2,5, 10,
11, 14, 19, 23, 27, 31, 33 Закону України від 10 грудня 2015 року «Про державну службу»), певні неоднозначні та нечіткі поняття та ознаки в назвах органів центральної виконавчої влади містяться й в Указі Президента України від 09 грудня 2010 року «Про оптимізацію системи центральних органів виконавчої влади»: «інфраструктура», «агентство», «енергоефективність», «з питань кіно», «управління зоною відчуження», «3 питань праці» тощо (зміст та сутність зазначених термінів та назв державних органів або ж не зафіксовані чинним законодавством, або дають підстави для довільного тлумачення завдань та функцій відповідних органів), і це далеко не повний перелік нормативних актів у цій сфері та оцінних понять у них [8, с.188-189].

Оціночні поняття можуть іноді знижувати ефективність адміністративної діяльності і навіть сприяти порушенням законності. Це відбувається у тому випадку, коли межі розсуду, встановлені оціночними поняттями, дуже широкі. У результаті частка суб'єктивного моменту істотно зростає, створюються сприятливі умови для відхилення від точного змісту закону [13, с.11].

Наприклад, проаналізувавши Кодекс України про адміністративні правопорушення, маємо велику кількість таких понять. Виходячи із сфери їх застосування неправомірне або некоректне їх тлумачення посадовою особою органів публічної адміністрації може негативним чином впливати на дотримання принципу законності застосування адміністративного розсуду, а саме на ступінь захисту прав та свобод особи або вирішення справи по суті. Серед оціночних понять, які можна зустріти - «суспільні шкідливі наслідки», «доцільно», «напіввільні умови», «правосвідомість», «неправомірна вигода», «заінтересованість», тощо.

Наведені особливості оціночних понять базуються на теоретичних доробках, у яких до основних ознак оціночних понять учені відносять такі: зміст правових оціночних понять не визначається в нормах законодавства; оціночні поняття, що містяться в нормах права, є сукупністю узагальнень різноманітних предметів, явищ, дій, процесів; оціночні поняття в праві фіксують найбільш 
загальні ознаки узагальнених в них явищ; конкретизація правових оціночних понять, визначення явищ i фактів навколишньої дійсності, що входять в обсяг оціночного поняття, стосовно до передбаченої законодавцем ситуації в процесі правозастосування здійснюеться шляхом їх оцінки; визначення змісту правових оціночних понять в процесі їх застосування залежить від правосвідомості особи, яка застосовує правову норму [12, c.215-221].

Підсумовуючи, необхідно зазначити, що саме удосконалення адміністративного законодавства $\epsilon$ чинником стабілізації суспільних відносин, що може бути досягнуто в результаті раціонального використання оціночних понять права, дослідження яких має велике науково-практичне значення.

На сьогоднішній день правова невизначеність поняття і особливостей застосування адміністративного розсуду у діяльності органів публічної адміністрації обумовлює тенденцію зростання порушень прав та свобод фізичних та юридичних осіб в адміністративно-публічних відносинах, тож окремі питання для з'ясування сутності та меж його застосування вирішуються судами.

Конкретизація оціночних ознак у процесі правозастосовчої діяльності вимагає систематичного аналізу адміністративно-правових норм і практики їх застосування правозастосовними органами, постійного обліку протиріч, які виникають у даній сфері. Це, в свою чергу, необхідно для вдосконалення правотворчої роботи, підтримки відповідності між змістом закону про адміністративну процедуру та реальними потребами суспільства.

Крім того, задача вирішення цих проблемних питань полягає в широкому використанні різноманітних способів нормативного врегулювання застосування оцінних понять.

У результаті було досягнуто висновку, що необхідно не тільки скоротити кількість і різноманітність оціночних понять в нормативних актах, оскільки, як було зазначено вище, це створює сприятливі умови для зловживання правом при можливості неоднозначного тлумачення оцінних понять при вирішенні певної справи, а також й закрі- пити безпосередньо в законодавстві тлумачення окремих оціночних понять, що заслуговує на увагу з боку правотворчих органів. В свою чергу це дозволить стандартизувати практику їх застосування та уникнути чисельних правозастосовчих помилок

В результаті дослідження встановлено, що один із методів удосконалення тлумачення та використання оціночних це повна або часткова відмова законодавця від використання таких понять 3 метою більш ефективного дотримування принципу законності при складанні базису для застосування, наприклад, певного виду адміністративного стягнення або іншого виду адміністративної санкції. Зрозуміло, що такі випадки підпадають до категорії радикальних мір, і матимуть місце лише у виключних випадках, тоді, коли не можливо уникнути негативних наслідків після застосування оціночних понять.

\section{Аітература}

1. Закон України «Про державну службу» // Відомості Верховної Ради (ВВР). 2016. - № 4. - ст.43.

2. Бару М.О. Оценочные понятия в трудовом законодательстве // Советское государство и право. - 1970. - № 7. - С. 104-108.

3. Веренкіотова О. В. Оціночні поняття у правових актах: теорія та практика реалізації: автореф. дис. ... канд. юрид. наук: 12.00.01 / О.В. Веренкіотова - К., 2013. - 20 с.

4. Веренкіотова О.В. Оціночні поняття у правових актах: теорія та практика реалізації: дис. ... канд. юрид. наук: 12.00.01 / О.В. Веренкіотова. - Київ, 2013. - 192 с.

5. Игнатенко В.В. Оценочые понятия в законодательстве об административной ответственности: дисс. ...канд. юрид. наук: 12.00.02 / В.В. Игнатенко. - Свердловск, 1989. - $191 \mathrm{c}$.

6. Коломоєць Т.О., Біленко В.А. Оціночні поняття в адміністративно-деліктному праві України: деякі аспекти їх функціонального призначення / Т.О. Коломоєць, В.А. Біленко. // Вісник Запорізького національного університету № 4. - 2010. - с. 80-84.

7. Косович В.М. Оцінювання й оцінки у національному й міжнародному правозахисті: [монографія] / В.М. Косович; редкол.: 


\section{Адміністративне право}

\section{АНОТАЦІЯ}

Стаття присвячена визначенню сутності очіночних понять через аналіз думок різних вчених правників вітчизняної та зарубіжної юридичної думки. За відсутності виваженого підходу до визначення очіночних понять у правозастосовній діяльності, їх тлумачення становить певні труднощі для суб'єктів правозастосування. Розмаїття $і$ широта сфери застосування очіночних понять в адміністративному праві є набагато більшими, ніж в інших галузях права, а тому потребує узагальнення та певної стандартизаиї. Зроблено висновок про необхіднісь систематичного аналізу адміністративно-правових норм, а також впровадження практики стандартизаиї їх застосування правозастосовними органами.

Ключові слова: очіночні поняття, адміністративний розсуд, дискреція, тлумачення, нормотворення, правозастосування

П.М. Рабінович та ін..; Академія правових наук України; Науково-дослідний інститут державного будівництва та місцевого самоврядування. - Аьвів: Світ, 2006. - 351 с.

8. Костенко О.I. Проблеми тлумачення оцінних понять в адміністративному законодавстві України / Костенко О.І. // Вісник Запорізького національного університету. Юридичні науки : зб. наук. пр. / Запорізький національний університет. - Запоріжжя : ЗНУ, 2011. - 2011. №1. - С. 187-193.

9. Аевина Д.Н. Теоретические проблемы толкования и применения оценочных понятий: автореф. дисс. ... канд.юрид.наук ... 12.00.01 / Д.Н. Аевина. - Нижний Новгород, 2007. - $36 \mathrm{c}$.

10. Моісеєнко Г.В. Визначення категорії «оціночні поняття» як складника понятійного апарату адміністративного судочинства України / Г.В. Моісеєнко // Науковий вісник УжНУ. Серія: Право. - № 29-2, частина 4/2. - С.92-96.

11. Рєзанов С.А. Оціночні поняття як нормативне закріплення адміністративного розсуду / С. А. Рєзанов // Вісник Національного університету внутрішніх справ. - 2004. Вип. 28. - С. 163-169. - Режим доступу: http:// nbuv.gov.ua/UJRN/VKhnuvs_2004_28_32

12. Семчик, О.О. Сучасні концепції оціночних понять у праві: до постановки питання / О. О. Семчик // Науковий вісник

\section{SUMMARY}

The article defines the meaning of the phenomenon of value judgments through the analysis of law scientists of national and foreign juridical thought. Wherein the balanced approach towards the unified definition of the value judgment is absent nowadays, their interpretation during the legislating process causes certain difficulties for the subjects of law enforcement. The variety and wide range of the application of value judgments in administrative law is more profuse than in any other sphere of law. The analysis of various sources, for its part, gives us the possibility to consider the application of value judgments either in doctrinal researches or law-making and law-enforcement activity. It's worth mentioning that in current conditions there is fundamental rethinking of doctrinal legal regulations concerning administrative process (relating to its understanding, circumstantial, legal basis etc.), which in future will serve as the ground to the future legislation, in the first place for all codified acts. Therefore, we pay so much attention to the grounded critical analysis of value judgments in administrative procedure, including the analysis of the prerequisites of their existence that provides elaborating relevant important recommendations pertaining to probable improvement of their application in future for the sake of guarantying the effectiveness of administrative procedure activity.

This article offers some propositions as for probable variants of enhancement of application of value judgments in law-making and lawenforcement activity.

Key words: value judgments, administrative discretion, discretion, interpreting, legislating (making laws), law enforcement

Академії муніципального управління. Сeрія: Право. - 2012. - Вип. 1. - С. 215-221.

13. Соловей Ю.П. Усмотрение в административной деятельности советской милиции: автореф. дисс. ...канд. юрид. наук: 12.00.02 / Ю.П. Соловей. - Москва, 1982. - 24 с.

14. Юридична енциклопедія : в 6 т. Т. 1 / редкол.: Ю. С. Шемшученко (голова редкол.) та ін. - К. : Укр. енцикл., 1998. - 400 с.

15. Черноус С.М. Оціночні поняття у трудовому праві України.: дисс. ...канд.. юрид.наук: 12.00 .05 / С.M. Черноус. - Харків, 2008. - 212 с. 